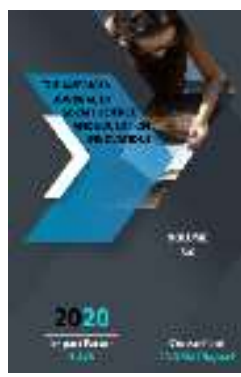

\title{
Significance Of Blended Learning In Education System
}

\author{
Avazmatova Marhabo Muxtorjonovna \\ Teacher, National University Of Uzbekistan, Uzbekistan
}

Journal Website: http://usajournalshub.c om/index,php/tajssei

\section{ABSTRACT}

Blended learning is the integration of traditional face-to-face learning with technology, the internet, and distance learning. This approach is becoming pervasive in the education system in recent years. Accordingly, the research paper examines the importance of blended learning in teaching. The objective of the article is to show reasons for using blended learning in education and essential factors of a successful blended course. The quality of the blended course can be enhanced by combining the advantages of both online and in-person learning. The article also provides other factors that can help to design a productive blended course. Overall, blended learning is an effective way of teaching that is flexible and easy to access. Moreover, it can increase students' motivation and their achievement of the course.

\section{KEYWORDS}

Blended learning, online learning, essential factors of blended learning, designing blended course.

\section{INTRODUCTION}

First of all, what is "Blended learning"? There are given many definitions in different sources. According to Graham.Ch et al (2019) "Blended learning is strategic combination of online and in-person instruction." Russel T. Osguthorpe and Charles R. Graham in 2003 stated that
Blended learning links face-to-face to distance conveyance framework, however, it is more than demonstrating a page from a website on the screen... the ones who utilize blended learning environments are attempting to boost the advantages of both face-to-face and online 
techniques. "Blended learning is the thoughtful integration of classroom face-toface learning experiences with online learning experiences" claimed Garrison and Kanuka (2004). "Blended learning combines online instruction components with those found in traditional face-to-face instructional environments" argued Dr. Ranjana Bhatia. John Watson stated "Blended learning, combining the best elements of online and face-to-face education, is likely to emerge as the predominant teaching model of the future". It can be concluded that Blended learning is integrating traditional face-to-face learning with technology and distance learning.

\section{MAIN FINDINGS AND RESULTS}

Why blended learning should be used in education system? Since technology entered humans' life and effected their living, it is also influencing their education system. In the past, when no technological devices were invented or they were rare, people take only face-to-face lessons traditionally. Now we are living gadgetfilled offices and houses, so it should be used positively. Instead of the rule "No smartphones in the lesson" as a teacher, we allow using "Any tech devices in the lessons including, mobile phones and laptops". Many young learners choose to use their devices all the time. When we persuade students not to use their mobile phones and put them in their bags, their mind is busy with how to take their gadgets and use it. If they do not use their laptops and mobile phones for education, they fill their time by playing video games or just on Instagram and Facebook just following their favorites and waste their time. Of course, either face-to-face learning or online learning has its disadvantages. For example, students easily might be bored with just sitting and listening to monotonous lectures in the classrooms or they suffer from long texts and useless graphs in their online classes. They must only read given materials and it is enough. It discourages and demotivates them because they do not discuss their findings with their partners with orally. In this circumstance, blended learning is a suitable solution for such kind of problem. There have been researches on the effectiveness of blended learning. Teachers can use innovative methodology involving Information and Computer technology in blended learning (Chen et al., 2005). In the article, "Blending traditional learning with online learning in teacher education" Dr. Ranjana Bhatia counted the following advantages of blended learning:

1. Greater efficiencies with group sizes;

2. Support professional/work-based skills development;

3. Flexible study, with learning on-demand, anytime or anywhere, to meet learners' needs wherever they want;

4. Wide access to digital resources, shared tools, and information systems.

According to Graham (2006), three main reasons why the blended learning is recommended:

a) Boosting up the effectiveness of education;

b) Increased access and convenience;

c) Greater cost-effectiveness.

The findings of El-Deghaidy and Nouby (2008) indicated that the achievement of students in the blended group is significantly higher than students, who studied in-person. Moreover, they found that students' attitudes towards elearning are essentially greater in blended group. El-Deghaidy and Nouby regarded blended learning as successful concerning attitudes and accomplishment. Blended learning is considered a supportive learning environment (Miyazoe and Anderson, 2010). It is also mentioned that blended learning 
decreased dropout rates and increased exam pass rates (Lopez-Perez et. Al., 2011). Jia et al. (2012) examined 96 middle school students in China who are taking English courses. They used moodle as a blended system management tool for experimental study. The results showed that blended learning with a vocabulary assessment system enhanced students' vocabulary acquisition as well as their exam performance. Smyth er.al (2012) conducted research to identify the benefits and challenges of blended learning in the school of Nursing and Midwifery in Ireland. The findings show that students find it easy to access and it is esteemed as a flexible course that assists them in learning and outlining. As challenges of the course, they mentioned three factors: difficulty of social interaction, late feedback from the teacher, and poor internet connection. In general, students showed positive feelings on blended learning (Smyth et. al., 2012). Either traditional learning or online learning has its advantages and disadvantages. Therefore, in blended learning, positive sides and strong aspects of face-toface and online education can be taken in order to complete each other. Discussion groups and different platforms such as Google Classroom, Quizizz can aid blended lessons. In general, blended learning is preferable for following reasons:

a) Easy to access resources;

b) Live feedback in the classroom;

c) Flexible lessons;

d) No need to large buildings.

In the blended learning, learners have a chance to ask their misunderstandings in the classrooms at the same time they take flexible online lesson no matter wherever they are and whenever. In addition, students can access course materials easily; they can read upcoming lesson materials such as articles beforehand and prepare to discuss it in the face-to-face lesson after that they can do online tasks based on the topic in order to reach a deeper understanding. On the contrary, in traditional education students come to the classroom knowing nothing about a new topic that is why they study it, go home, and consolidate they do home tasks. Moreover, if they apply blended learning rather than the traditional one, educational organizations do not have to have large buildings for students. When one group of students are taking in-person instructions, other groups can take online lessons.

The next important factor is how to blend lessons effectively. When designing a blended course each learning style should be taken into consideration. For example, texts, pictures, and diagrams, presentation slides ought to be implemented for Visual learners. Auditory learners prefer podcasts, audio files, and lectures in their lessons. Kinesthetic learners acquire new things by imitating, trying, holding, and feeling things. The deeper learning comes from doing things. For example, many English learners know everything in textbooks but they have difficulty ordering a coffee in an English speaking country. Therefore, when planning the blended course there should not be given only texts, presentation slides, or videos. Different type of materials ought to be given in a mixed way that students do not get bored and each type of learners obtain the given information advantageously. In order to blend lessons effectively some other factors also ought to be taken into account:

1. Enrollment-Have the students enrolled for the lesson. How many students have enrolled? Firstly, before beginning the course, the teacher should know about student enrollment. In order to attract 
more students, the syllabus ought to be designed appropriately.

2. Activity-different and innovative activities play an important role in the course designing. During the course, teacher control that students are doing activities or they engage with the content of the lesson.

3. Completion-in order all students complete, during the course teacher should motivate and encourage them to participate in all the lessons and submit assignments on the time. In the end, teachers do statistics about how many students complete the course or they reach till the end.

4. Score- in order to complete the course successfully how many score students should take? Is there a single score for the course? Or, are there several scores for the modules?

\section{CONCLUSION}

Altogether, these findings show the importance of blended learning in teaching, for it is the bridge of promoting students' knowledge breadth and depth. In a technologically developed era, using only inperson instruction is fruitless for electronicloved students. Alternatively, adopting solo online learning has its demerits such as late feedback, difficulty with the engagement of students, social isolation, and lack of motivation. One last word must be said that, by designing a blended course effectively and integrating positive sides of online and face-toface education, ones can reach mastery of the content. Adopting technology in the education system and blended learning is valuable in the academic world therefore; it can be further studied and made new concepts.

\section{REFERENCES}

1. Bhatia R. Blending traditional learning with online learning in teacher education.
International Conference, Delhi University. 26-28 Feb 2007.

2. Chen, N.-S., Ko, H.-C., Kinshuk, \& Lin, T. (2005). A model for synchronous learning using the Internet. Innovations in Education and Teaching International, 42(2), 181-194.

3. El-Deghaidy, H., \& Nouby, A. (2008). Effectiveness of a blended e-learning cooperative approach in an Egyptian teacher education programme. Computers \& Education, 51(3), 988-1006.

4. Garrison, D.R., \& Kanuka, H. (2004). Blended learning: Uncovering its transformative potential in higher education. Internet and Higher Education, 7(2), 95-105.

5. Graham, C. R. (2006). Blended learning systems: definition, current trends, and future directions. In Handbook of Blended Learning: Global Perspectives Local Designs, edited by C. J. Bonk and C. R. Graham, pp. 3-21.

SanFrancisco, CA: Pfeiffer Publishing.

6. Graham, Ch. R., Borup, J., Short, C. R., \& Archambault., L. (2019). K-12 Blended

Teaching: A Guide to Personalized Learning and Online Integration, 11-12. http://edtechbooks.org/k12blended

7. Jia, J., Chen, Y., Ding, Z., \& Ruan, M. (2012). Effects of a vocabulary acquisition and assessment system on students' performance in a blended learning class for English subject. Computers \& Education, 58(1), 63-76.

8. López-Pérez, M., Pérez-López, M. C., \& Rodríguez-Ariza, L. (2011). Blended learning in higher education: Students' perceptions and their relation to outcomes. Computers \& Education, 56(3), 818-826.

9. Miyazoe, T., \& Anderson, T. (2010). Learning outcomes and students' perceptions of online writing: Simultaneous implementation of forum, 
blog, and wiki in an EFL blended learning setting. System, 38(2), 185-199.

10. Osguthorpe, R.T. \& Graham, C.R. (2003). Blended Learning Environments: Definitions and Directions. Quarterly Review of Distance Education, 4(3), 227. Retrieved August 23, 2020 from https://www.learntechlib.org/p/97576/.

11. Smyth, S., Houghton, C., Cooney, A., \& Casey, D. (2012). Students' experiences of blended learning across a range of postgraduate programmes.Nurse education today, 32(4), 464-468.

12. Watson, J. (2008). Blended Learning: The Convergence of Online and Face-to-Face Education. Promising practices in online learning. North American Council for online learning, pp-4. 